\title{
UJI POTENSI ANTIBAKTERI KOMBINASI EKSTRAK AIR ALLIUM CEPA L DAN ANDROGRAPHIS PANICULATA NESS TERHADAP PSEUDOMONAS AERUGINOSA
}

\author{
Merliana Sari Situmeang1, MM. Suryani Hutomo², Yanti Ivana Suryanto ${ }^{3}$ \\ ${ }^{1}$ Fakultas Kedokteran, Universitas Kristen Duta Wacana \\ ${ }^{2}$ Bagian Mikrobiologi, Fakultas Kedokteran, Universitas Kristen Duta Wacana \\ ${ }^{3}$ Bagian Fisiologi, Fakultas Kedokteran, Universitas Kristen Duta Wacana
}

Korespondensi: suryanihutomo_drg@yahoo.com

\begin{abstract}
ABSTRAK
Bawang bombay (Allium cepa L) dan sambiloto (Andrographis paniculata Ness) merupakan tumbuhan yang sering kita jumpai di sekitar kita. Allium cepa $L$ dan Andrographis paniculata Ness secara terpisah telah diteliti dapat menghambat pertumbuhan Pseudomonas aeruginosa. Penelitian dilakukan untuk mengetahui potensi antibakteri kombinasi Allium cepa L dan Andrographis paniculata Ness terhadap bakteri Pseudomonas aeruginosa. Kedua tanaman tersebut diekstraksi dengan metode infusa menggunakan pelarut air. Uji daya hambat dilakukan menggunakan metode difusi dengan mengukur diameter zona hambat. Penelitian pendahuluan dilakukan untuk menentukan konsentrasi terendah yang sudah memiliki zona hambat dan didapatkan konsentrasi 25\% untuk masing-masing ekstrak, maka konsentrasi inilah yang digunakan sebagai kombinasi. Data yang diperoleh dianalisis dengan menggunakan uji One Way Anova kemudian dilanjutkan dengan uji LSD. Hasil penelitian menunjukkan bahwa terdapat peningkatan zona hambat yang signifikan secara statistik $(\mathrm{p}=0,00, \mathrm{p}<0,05)$ pada kombinasi Allium cepa L dan Andrographis paniculata Ness dibanding sediaan tunggal. Kesimpulan penelitian ini adalah terdapat peningkatan potensi antibakteri terhadap bakteri $P$. aeruginosa.
\end{abstract}

Kata Kunci: Allium cepa L, Andrographis paniculata Ness, antibakteri. 


\title{
POTENTIAL EFFECTS OF ALLIUM CEPA L AND ANDROGRAPHIS PANICULATA NESS AQUEOUS EXTRACT AGAINST PSEUDOMONAS AEROGINOSA
}

\author{
Merliana Sari Situmeang1, MM. Suryani Hutomo ${ }^{2}$, Yanti Ivana Suryanto ${ }^{3}$ \\ ${ }^{1}$ Medical Faculty of Duta Wacana Christian University \\ ${ }^{2}$ Microbiology Division, Medical Faculty of Duta Wacana Christian University \\ 3Physiology Division, Medical Faculty of Duta Wacana Christian University \\ Corespondence: suryanihutomo_drg@yahoo.com
}

\begin{abstract}
Allium cepa L and Andrographis paniculata Ness are plants often we found arround us. Allium cepa $L$ and Andrographis paniculata Ness has been observed to inhibit the growth of Pseudomonas aeruginosa. The study was conducted to determine the potencial of the combination water extract of Allium cepa $L$ and Andrographis paniculata Ness against Pseudomonas aeruginosa. Both plants were extracted with infusa method using aquades. The inhibition test performed using a diffusion method to measure the diameter of inhibition zone. Preliminary research conducted to determine the lowest concentration that have inhibitory zone and found concentration of $25 \%$ for each of the extracts, the concentration is used as a combination. Data were analyzed by using One Way Anova then continued with LSD test. The results showed that there was an increase in the inhibition zone was statistically significant ( $p=0.00, p<0.05)$ in combination Allium cepa $L$ and Andrographis paniculata Ness compared to single dosage. The conclusion is that there is an increase of antibacterial potency against $P$. aeruginosa bacteria.
\end{abstract}

Keywords: Allium cepa L, Andrographis paniculata Ness, antibacterial. 


\section{PENDAHULUAN}

Pseudomonas adalah bakteri oportunistik patogen pada manusia, spesies yang paling banyak menyebabkan infeksi adalah $P$. aeruginosa. Bakteri ini bersifat Gram negatif, berbentuk batang dan bergerak dengan flagella monothrichous. Habitat utamanya adalah daerah lembab seperti di tanah, saluran air dan daerah lembab di tubuh manusia. Transmisi Pseudomonas dapat berasal dari air yang terkontaminasi maupun kontak langsung dengan bagian tubuh yang mengalami luka. ${ }^{1}$ Pseudomonas aeruginosa merupakan penyebab utama infeksi nosokomial terutama pada pasien yang menggunakan ventilator, kateter, pasca operasi, serta ditemukan pada berbagai peralatan yang terdapat di rumah sakit. Sebanyak $30-40 \%$ pasien dengan fibrosis kistik mengalami infeksi nosokomial kronis. Infeksi nosokomial akibat $P$. aeruginosa juga dialami oleh $20 \%$ dari penderita pneumonia dan $16 \%$ dari penderita infeksi saluran kemih. ${ }^{2}$ Angka mortalitas karena infeksi $P$. aeruginosa cukup tinggi karena resistensinya terhadap antibiotik. Penyebaran bakteri ke berbagai tempat di bagian tubuh serta kemampuan $\quad P$. aeruginosa menghasilkan protease yang dapat merusak jaringan menyebabkan komplikasi yang mengancam jiwa. ${ }^{3}$

Pencegahan infeksi pada tenaga medis diusahakan dengan cara melakukan edukasi terhadap tenaga medis. Kontrol risiko penularan mikroorganisme dari peralatan dan lingkungan dilakukan melalui tindakan pembersihan, desinfeksi dan sterilisasi. Sodium hipoklorit merupakan salah satu desinfektan yang sering digunakan untuk desinfeksi peralatan rumah sakit yang sangat efektif untuk membunuh bakteri dan virus sehingga banyak digunakan di rumah sakit. Meskipun demikian, penggunaan desinfektan kimia secara terus-menerus dan berlebihan dikhawatirkan dapat menimbulkan kerusakan lingkungan. Berdasarkan hal tersebut perlu dicari alternatif yang ramah lingkungan tetapi mampu untuk menanggulangi bakteri tersebut. Salah satu alternatif yang dapat digunakan sebagai pengganti desinfektan kimia adalah bahan-bahan alami. ${ }^{3}$

Bahan alami yang berpotensi sebagai antibakteria adalah ekstrak bawang bombay (Allium cepa L) dan ekstrak daun sambiloto (Andrographis paniculata Ness). Penelitian yang dilakukan Wuryanti dan Munrah) melaporkan bahwa ekstrak air bawang bombay memiliki sifat antibakteri terhadap $P$. aeruginosa. ${ }^{4}$ Kandungan fenol dan flavanoid dari Allium cepa $L$ berpotensi menghambat pertumbuhan bakteri. Dari hasil uji antibakteri tersebut, ekstrak air Allium cepa L 100\% memiliki daya hambat paling luas. Semakin pekat ekstrak maka semakin kuat daya hambat terhadap pertumbuhan bakteri.

Penelitian lain melaporkan bahwa sambiloto (Andrographis paniculata Ness) juga merupakan salah satu tanaman obat yang memiliki efek antibakteri. Tanin, fenol, flavanoid dan androgapholida adalah zat aktif pada ekstrak Andrographis paniculata Ness yang diduga dapat bersifat antibakteri. Pada penelitian yang dilakukan oleh Sulistiowati dkk. ${ }^{5}$ mengenai efek antibakteri sambiloto terhadap $P$. aeruginosa, melaporkan bahwa semakin tinggi konsentrasi ekstrak air Andrographis paniculata Ness maka semakin rendah pertumbuhan $P$. aeruginosa. Ekstrak air Allium cepa $L$ memiliki efek antibakteri namun masih rendah begitu juga dengan ekstrak air Andrographis paniculata Ness. 
Penelitian mengenai kombinasi dua ekstrak pernah dilakukan oleh Yuniarti mendapatkan hasil bahwa kombinasi infus daun sirih dan daun salam dapat meningkatkan daya hambat pertumbuhan Staphylococcus aureus invitro dibandingkan dengan sediaan tunggal. ${ }^{6}$ Pada penelitian ini dilakukan kombinasi dari Allium cepa $L$ dan Andrographis paniculata Ness untuk menilai potensi antibakteri yang dihasilkan. Keberhasilan penelitian ini diharapkan dapat menjadi salah satu alternatif antibakteri terhadap bakteri $P$. aeruginosa. Penelitian ini telah mendapat persetujuan etik dari Komite Etik Fakultas Kedokteran Universitas Kristen Duta Wacana nomor 124/C.10/FK/UKDW/V/2015.

\section{METODE PENELITIAN}

\section{Penyiapan ekstrak air Allium cepa $L$ dan Andrographis paniculata Ness}

Penyiapan ekstrak air Allium cepa $L$ dan Andrographis paniculata Ness dilakukan di Laboratorium penelitian dan Pengujian Terpadu (LPPT) Universitas Gadjah Mada Yogyakarta. Ekstrak dibuat dari $1 \mathrm{~kg}$ Allium cepa L dan $1 \quad \mathrm{~kg}$ daun Andrographis paniculata Ness.

\section{Kultur $P$. aeruginosa ATCC 27853}

Pseudomonas aerugnosa ATCC 27853 merupakan koleksi Laboratorium Mikrobiologi Fakultas Kedokteran UKDW. Bakteri dikultur pada media BHI cair, kemudian diinkubasi pada suhu $37^{\circ} \mathrm{C}$ selama 24 jam. Suspensi dibuat menggunakan standar 0,5 Mc Farlan.

\section{Pengujian antibakteri}

Pengujian aktivitas antibakteri dilakukan dengan metode difusi cakram untuk mengetahui ada tidaknya aktivitas antibakteri dari masing-masing ekstrak air Allium cepa $L$ dan Androgaphis paniculata Ness, maupun campuran kedua jenis ekstrak tersebut. Media yang digunakan adalah Mueller Hinton Agar (MHA). Bakteri diinokulasikan pada agar secara merata, blank-disk yang sudah direndam ekstrak diletakkan pada media. Media kemudian diinkubasi pada suhu $37^{\circ} \mathrm{C}$ selama 24 jam. Setelah inkubasi, dilakukan pengukuran zona hambat bakteri ${ }^{4}$. Pengukuran zona hambat dilakukan dengan mengukur zona jernih yang terbentuk di sekitar disk. Pengukuran zona hambat ini dilakukan menggunakan penggaris/ mistar.

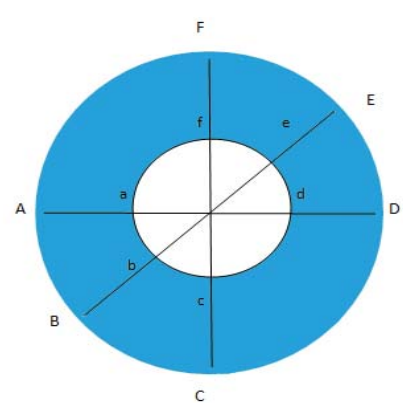

Gambar 1. Cara pengukuran zona hambat: Diameter zona hambat: A-D, B-E, C-F 


\section{Analisis Statistik}

Data diuji normalitasnya dengan uji Shapiro Wilk dan uji homogenitas dengan Levene's test, distribusi data dikatakan normal jika harga $\mathrm{p}>0,05$ dengan interval kepercayaan 95\%. Apabila kedua uji menunjukkan data terdistribusi normal dan homogen maka dilakukan uji statistik parametrik menggunakan metode analysis of variance (anova) untuk melihat perbandingan zona hambat kombinasi ekstrak dibanding sediaan tunggal ekstrak.

\section{HASIL PENELITIAN}

Hasil penelitian menunjukkan bahwa kombinasi ekstrak Allium cepa L 25\% dan Andrographis paniculata Ness 25\% yang diinkubasi selama 24 jam memiliki zona hambat lebih luas daripada sediaan tunggal. Diameter dan rerata zona hambat tercantum pada Tabel 1. dan besarnya zona hambat tercantum pada Gambar 2.

Tabel 1. Besar zona hambat

\begin{tabular}{lcccc}
\hline \multicolumn{1}{c}{ Ekstrak } & \multicolumn{4}{c}{ Zona Hambat (mm) } \\
\cline { 2 - 5 } & \multicolumn{1}{c}{$\boldsymbol{P}$. aeruginosa } & Rerata \\
\hline Allium cepa L 25\% & 13 & 14 & 15 & 14 \\
Andrographis Paniculata Ness 25\% & 13 & 14 & 12 & 13 \\
Kombinasi (petri 1) & 20 & 21 & 22 & \\
Kombinasi (petri 2) & 20 & 21 & 18 & 20,3 \\
Kombinasi (petri 3) & 20 & 21 & 20 & \\
Kontrol + (NaOCl) & 22 & 22 & 21 & 21,7 \\
Kontrol - (akuades) & 0 & 0 & 0 & 0 \\
\hline
\end{tabular}
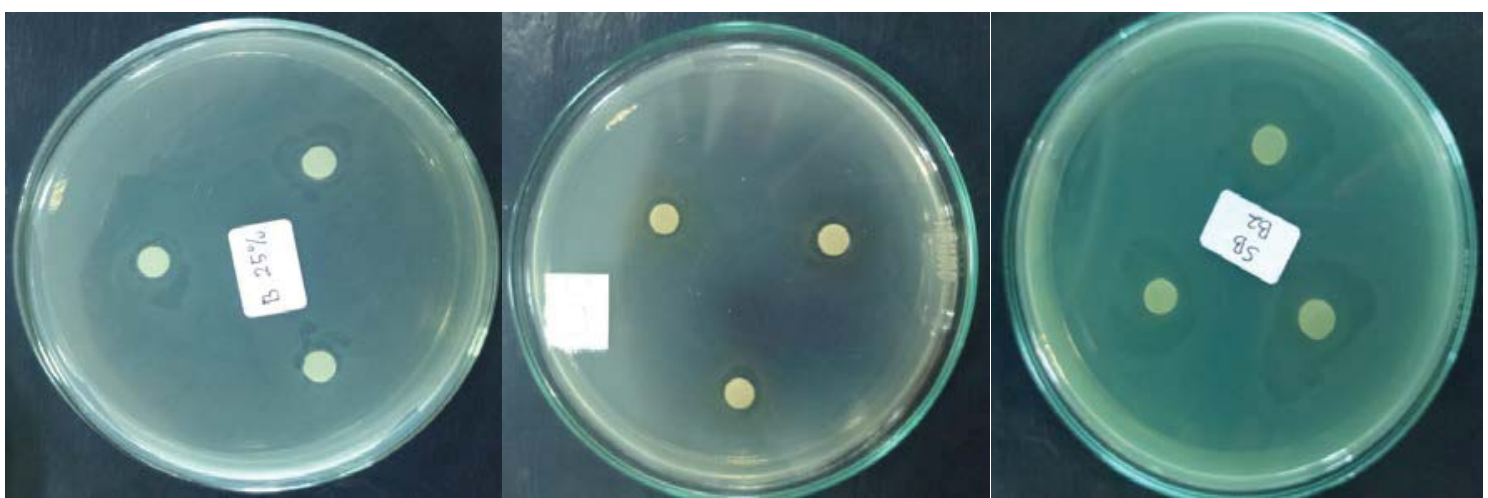

Gambar 2. (A) Zona hambat ekstrak Allium cepa L 25\%, (B) Zona hambat ekstrak Andrographis paniculata Ness 25\%, (C) Zona hambat kombinasi ekstrak Allium cepa L 25\% dan Andrographis paniculata Ness 25\%,

\section{DISKUSI}

Penelitian yang dilakukan Wuryanti dan Munrah melaporkan bahwa ekstrak air bawang bombay (Allium cepa L) memiliki sifat antibakteri terhadap $P$. aeruginosa. Kandungan fenol dan flavanoid dari Allium cepa $L$ berpotensi menghambat pertumbuhan bakteri. ${ }^{4}$ Hal ini sesuai dengan penelitian yang dilakukan. Berdasarkan penelitian ini didapatkan ekstrak Allium cepa $L$ dengan konsentrasi 25\% sudah memiliki efek antibakteri.

Penelitian efek antibakteri sediaan tunggal ekstrak Andrographis paniculata Ness terhadap $P$. aeruginosa diperoleh hasil yang sesuai dengan penelitian Sulistiowati dkk. 
mengenai efek antibakteri sambiloto terhadap $P$. aeruginosa yaitu terdapat hubungan antara konsentrasi sambiloto dengan pertumbuhan $P$. aeruginosa. ${ }^{5}$

Penelitian yang dilakukan oleh Yuniarti melaporkan bahwa kandungan ekstrak Andrographis paniculata Ness terdiri dari senyawa fenol dan derivatnya mempunyai daya antibakteri dengan cara menurunkan tegangan permukaan sel dan denaturasi protein. ${ }^{6}$ Adanya fenol yang merupakan senyawa toksik mengakibatkan struktur tiga dimensi protein terganggu dan terbuka menjadi struktur acak tanpa adanya kerusakan pada struktur kerangka kovalen. Hal ini mengakibatkan protein berubah sifat. Deret asam amino protein tersebut tetap utuh setelah berubah sifat, namun aktivitas biologisnya menjadi rusak sehingga protein tidak dapat melakukan fungsinya.

Senyawa aktif yang terkandung pada ekstrak mendenaturasi protein sel maka semua aktivitas metabolisme sel dikatalisis oleh enzim sehingga bakteri tidak dapat bertahan hidup. Protein yang mengalami denaturasi akan kehilangan aktivitas fisiologis sehingga tidak dapat berfungsi dengan baik. Perubahan struktur protein pada dinding sel bakteri akan meningkatkan permeabilitas sel sehingga pertumbuhan sel akan terhambat dan kemudian sel menjadi rusak. Flavonoid selain berfungsi sebagai bakteriostatik juga berfungsi sebagai anti inflamasi. ${ }^{6}$

Ekstrak

Andrographis paniculata Ness mengandung senyawa yang memiliki efek antibakteri antara lain tanin dan flavanoid. Tanin merupakan polifenol yang larut dalam air. Mekanisme antibakteri tanin antara lain menghambat enzim ekstra seluler mikroba, mengambil alih substrat yang dibutuhkan pada pertumbuhan mikroba, atau bekerja langsung pada metabolisme dengan cara menghambat fosforilasi oksidasi. Ekstrak Allium cepa $L$ juga mengandung senyawa yang sama seperti pada Andrographis paniculata Ness yaitu fenol dan flavanoid. Penggabungan dari kedua ekstrak menghasilkan peningkatan zona hambat yang signifikan. Hal ini kemungkinan karena senyawasenyawa aktif pada kedua ekstrak berkerja sinergis dalam mengganggu fungsional bakteri. Kombinasi ekstrak Allium cepa L 25\% dan Andrographis paniculata Ness 25\% setara dengan natrium hipoklorit 5,25\%. Untuk menghasilkan $40 \mathrm{ml}$ ekstrak Allium cepa L 25\% dibutuhkan 170 gr Allium cepa $L$ dan untuk $40 \mathrm{ml}$ Andrographis paniculata Ness 25\% dibutuhkan 100 gr Andrographis paniculata Ness kering.

Penelitian yang dilakukan oleh Sawitti dkk., melaporkan bahwa ekstrak Andrographis paniculata Ness secara signifikan mampu menghambat pertumbuhan bakteri Escherichia coli. ${ }^{7}$ Hasil dari penelitian ini diharapkan dapat digunakan sebagai desinfektan alami. Manfaat penggunaan ekstrak Allium cepa $L$ dan Andrographis paniculata Ness sebagai desinfektan alami salah satunya untuk menghindari efek samping dari natrium hipoklorit yang apabila terpapar kulit dapat menyebabkan kulit kemerahan, nyeri, rasa terbakar dan lecet. Penelitian ini masih memerlukan penelitian lebih lanjut untuk menentukan zat aktif lain yang diduga memiliki sifat antibakteri. Penelitian potensi antibakteri menggunakan tanaman Andrographis paniculata Ness dari daerah lain juga diperlukan untuk melihat apakah ada perbedaan zona hambat yang terbentuk.

\section{KESIMPULAN}

Berdasarkan hasil penelitian ini dapat disimpulkan, bahwa terdapat peningkatan potensi antibakteri 
Allium cepa $L$ dan Andrographis paniculata Ness terhadap bakteri $P$. aeruginosa.

\section{DAFTAR PUSTAKA}

1. Public Health Agency of Canada. Pseudomonas Spp. Available from :http:/www.phac-aspc.gc.ca/labbio/res/psds-ftss/pseudomonasspp-eng.php. [Accessed 19/11/ 2014] 30 April 2012.

2. CDC. Healthcare-assosiated Infection (HAIs). Available from : http:/www.cdc.gov/hai/organism s/pseudomonas.html.[Accessed 19/11/2014] 2 April 2013.

3. Nasution, L.H. (2012). Infeksi Nosokomial. Medan: Departemen/ SMF Ilmu Kesehatan Kulit dan Kelamin FK USU

4. Wuryanti \& Munrah. Uji Ekstrak Bawang Bombay Terhadap
Bakteri Gram Negatif Pseudomonas Aeruginosa dengan Metode Difusi Cakram. Semarang. UNDIP. 2009.

5. Sulistiowati, D., Baskoro, A.D., \& Winarsih, S. Uji Efektivitas Dekok Sambiloto (Andrographis paniculata) Sebagai Antibakteri Terhadap Pseudomonas aeruginosa Secara In Vitro. Malang: FK Universitas Brawijaya. 2010.

6. Yuniarti, T. (2008). Ensiklopedia Tanaman Obat Tradisional. Yogyakarta: Media presindo.

7. Sawitti, MY., Hapsari Mahatmi, I Nengah Kerta Besung. Daya Hambat Perasan Daun Sambiloto Terhadap Pertumbuhan Bakteri Escherichia coli. Indonesia Medicus Veterinus 2(2) : 142 - 150. 2013. 